\title{
Extracting female inbred lines from commercial sunflower hybrids
}

\author{
Claudio Guilherme Portela de Carvalho(1) and José Francisco Ferraz de Toledo(1)
}

(1)Embrapa Soja, Caixa Postal 231, CEP 86001-970 Londrina, PR. E-mail: cportela@cnpso.embrapa.br, toledo@cnpso.embrapa.br

\begin{abstract}
The objective of this study was to obtain female inbred lines from sunflower (Helianthus annuus) hybrids. A methodology based on altering inbred lines carrying the fertility restorer gene (Rf) obtained from self pollinating hybrids into inbred lines with normal cytoplasm without the Rf gene was described. Further, derived male-sterile inbred lines were developed. The methodology was successfully used to obtain female inbreds from sunflower commercial hybrids. Although more time and labor consuming than the conventional female inbred line extraction methods, this methodology is advantageous in exploiting superior germplasms (commercial hybrids), which prompted us to develop practical procedures to allow its routinely use.
\end{abstract}

Index terms: Helianthus annuus, cytoplasmic male sterility, fertility restoration, plant breeding, sunflower hybrid production.

\section{Extração de linhagens fêmeas a partir de híbridos comerciais de girassol}

Resumo - O objetivo desse trabalho foi obter linhagens fêmeas a partir de híbridos de girassol (Helianthus annuus). A metodologia foi descrita com base na alteração de linhagens com o gene restaurador de fertilidade (Rf), obtidas da auto-fecundação dos híbridos, em linhagens com citoplasma normal e sem o gene Rf. Em seguida, linhagens macho-estéreis foram desenvolvidas. Com o uso dessa metodologia foi possível obter linhagens fêmeas, a partir de híbridos comerciais de girassol. Apesar de essa requerer maior tempo e mão-de-obra do que o procedimento usual de obtenção de linhagens fêmeas, essa metodologia tem a vantagem de propiciar a exploração de germoplasmas superiores (híbridos comerciais), o que estimulou a descrição de procedimentos que permitam tornar a metodologia mais rotineira.

Termos para indexação: Helianthus annuus, macho-esterilidade citoplasmática, restauração de fertilidade, melhoramento de plantas, produção de híbridos de girassol.

\section{Introduction}

Comercial sunflower (Helianthus annuus L.) hybrid production usually relies on cytoplasmic male sterility (CMS) associated to a genetic system for fertility restoration (Miller \& Fick, 1997). In this process, the female parental inbred line is a CMS-HA, which carries the male-sterile cytoplasm trait (S-type cytoplasm) but no fertility restorer gene (Rf) in the nucleus. The female parent is, therefore, a male-sterile inbred line with S-rfrf genotype. The male parental line is a RHA inbred line, which can carry a normal $(\mathrm{N})$ or S-type cytoplasm, but must necessarily carry the Rf gene. Therefore, the RHA inbred is male-fertile with either S-RfRf or N-RfRf genotype. The resulting hybrid is male-fertile with S-Rfrf genotype.

Inbred lines with the fertility restorer gene (RHA inbred lines) can be developed by selfing commercial hybrids followed by selection of male-fertile plants from the segregant population (Miller \& Vick, 2001;
Miller et al., 2002, 2006a, 2006b; Miller \& Gulya, 2006). These inbreds should be submitted to progeny testing to ensure they have the S-RfRf genotype. On the other hand, cytoplasmic male-sterile inbreds (CMS-HA inbreds) can be developed by backcrossing, in which the nonrecurrent parent is any inbred line with S-type cytoplasm, and the recurrent one is usually a HA inbred line carrier of the N-rfrf genotype previously improved by several selection cycles. In sunflower breeding programs, HA inbreds are maintainers of CMS-HA inbreds and are derived from other HA inbreds (Miller \& Vick, 2001, 2002; Miller \& Seiler, 2003; Miller \& Gulya, 2006; Miller et al., 2006a, 2006b, 2006c). This procedure is practical and commonly used, however, the possibility of obtaining HA inbreds and, consequently, CMS-HA inbreds from commercial hybrids, as is currently done for the RHA inbreds, is an interesting alternative, since it would tap on the genetic potential of adapted genotypes with desirable traits. In this context, the objective of the present study was to 
breed female inbred lines from sunflower hybrids and report on the methodology used to obtain the described results.

\section{Materials and Methods}

Female inbred lines from sunflower hybrids were developed from RHA inbreds with S-RfRf genotypes obtained by selfing the hybrids. Those RHA inbreds were first altered to HA inbred lines with N-rfrf genotypes and, then, to cytoplasmic male-sterile inbred lines with S-rfrf genotypes.

The RHA inbreds were altered into HA inbreds by successive backcrosses using a selected HA line as female nonrecurrent parent and the RHA inbred as male recurrent parent (Figure 1). In those crosses, since the female parent ( $\mathrm{HA}$ and $\mathrm{F}_{1}$ and $\mathrm{BC}_{\mathrm{n}}$ generations) carried a normal cytoplasm, they needed to be previously emasculated. In each backcross generation, emasculated flowers in the central regions of the sunflower heads of $\mathrm{BC}_{\mathrm{n}}$ plants, which were homozygotes or heterozygotes for the $\mathrm{Rf}$ gene, received pollen from the recurrent parent to produce the $\mathrm{BC}_{\mathrm{n}+1}$ seeds. Only seeds from plants heterozygous for the $\mathrm{Rf}$ locus proceeded to the next generation.

To differentiate the heterozygous from the homozygous $\mathrm{Rf}$ plants, test crosses with CMS-HA lines were performed. The progeny from the CMS-HA line with the heterozygous Rf parent included fertile and sterile plants, while the homozygous Rf parent included only fertile plants. In sunflower, anthesis of flowers in the outer ring of the head happens before that

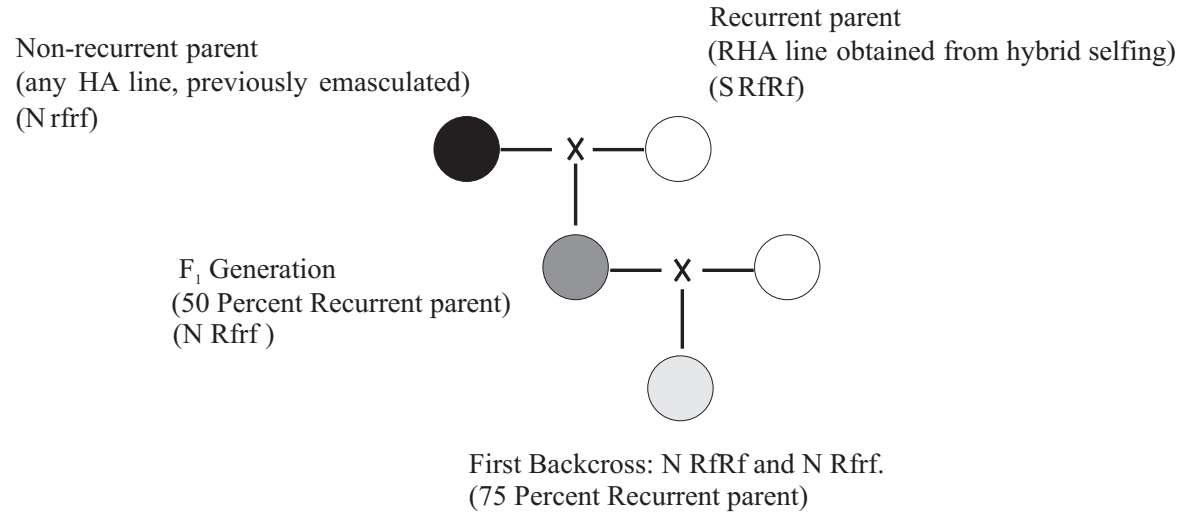

To check whether the $\mathrm{BC} 1$ plants are heterozygotes proceeds as follows:

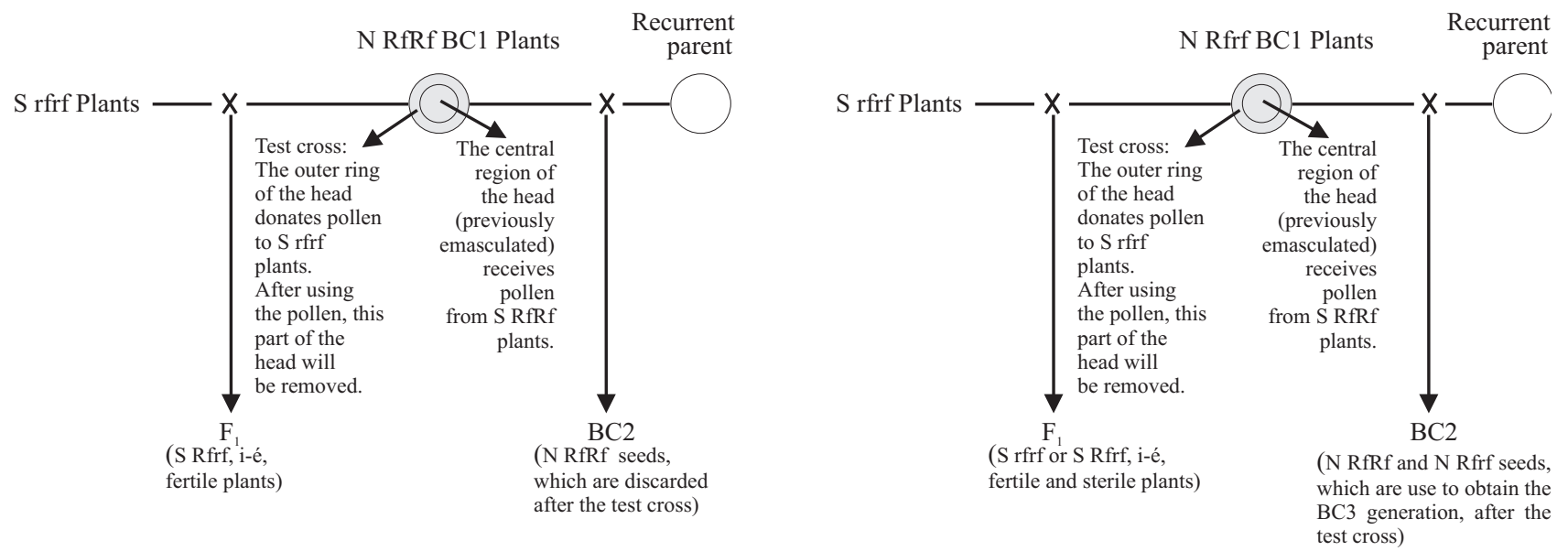

Figure 1. Obtaining normal cytoplasm sunflower inbred lines that are heterozygous or homozygous for the Rf gene (fertility restorer) 
of flowers in the central region. Consequently, for these test crosses, flowers in the outer ring of the head of the $\mathrm{BC}_{\mathrm{n}}$ plants donated pollen to any male-sterile line and needed to be subsequently removed from the head, to prevent fertilization of flowers from the central region which were expected to form $\mathrm{BC}_{\mathrm{n}+1}$ hybrid seeds.

After successive backcrossings $\left(\mathrm{BC}_{\mathrm{n}}\right)$, individual RfRf and Rfrf plants were selfed, and screened through crossing as males to pollinate CMS-HA inbred lines. Progenies derived from Rfrf plants contained HA (N-rfrf) and RHA (N-RfRf or N-Rfrf) plants. These progenies were selfed, and the HA plants were screened from RHA through test crosses to CMS inbreds. An alternative was to self pool RfRf and Rfrf plants from $\mathrm{BC}_{\mathrm{n}}$ generation and to test cross in the $\mathrm{BC}_{\mathrm{n}+1}$, but the formerly described procedure was used in this study.

Cytoplasmic male-sterile inbred lines (S cytoplasm) were, then, obtained by backcrossing the available HA (N-rfrf) inbreds as recurrent parent with selected CMS-HA inbreds (Miller \& Fick, 1997). The $\mathrm{F}_{1}$ generation was obtained as in the previous procedure, where there was discrimination between HA and RHA plants from a cross between a selected CMS-HA inbred and $\mathrm{rfr}$ lines from $\mathrm{BC}_{\mathrm{n}+1}$. The process followed as any backcrossing system with male-sterile plants crossed to the HA parental.

CMS-HA inbred lines were derived from 10 RHA inbred lines obtained by selfing and selecting plants from several Brazilian commercial hybrids without recording their origin. Only genotypes expressing monogenic fertility restoration for the CMS PET1 were used. For the CMS-HA developing process, the RHA inbreds were first altered into HA inbreds, through three backcrossings to the HA 300 inbred (USDA-ARS public inbred line) used as nonrecurrent parent. The RfRf and Rfrf plants from the third backcross generation were, then, selfed and identified through test-crosses to the CMS HA 300 inbred line. This CMS-HA inbred was also used to screen HA (N-rfrf) plants from RHA plants obtained in the progeny from Rfrf selfed plants. Then, the HA inbreds were altered to CMS-HA, through three backcrosses to the HA 300 inbred line used as nonrecurrent parent, according to the procedures described by Miller \& Fick (1997). All crosses performed to alter RHA into Ha plants were carried out in green-house environment, to obtain a high control of the experimental conditions. However, those for the introduction of male sterility in HA plants were carried out in the experimental field, as is routinely done in the breeding programs.

\section{Results and Discussion}

Cytoplasmic male-sterile inbred lines from all RHA inbreds included in this study were obtained using the proposed methodology. The usual procedure to obtain female sunflower inbred lines for hybrid production requires successive selfing of HA inbreds and incorporation of cytoplasmic male sterility in these endogamous HA plants (Miller \& Fick, 1997). The methodology described and adopted in this study, in addition to derive RHAinbreds and introduce cytoplasmic male sterility into HA inbreds, required conversion of RHA inbreds to HA inbreds, which demanded five breeding cycles equivalent to three years (Figure 1). Although time and labor-intensive, this procedure was advantageous because it allowed exploiting the genetic potential of hybrids adapted to the cropping region.

In our studies, only genotypes expressing monogenic fertility restoration for the CMS PET1 were used, because in more than $40 \mathrm{CMS}$ sources identified since the discovery of the CMS PET1, by Leclercq in 1968, from a cross between $H$. petiolaris and $H$. annuus, fertility restoration has been found to be predominantly controlled by either one or two genes (Serieys, 1996). Also, the large majority of the commercial hybrids uses the single gene CMS PET1.

The feasibility of transforming the process of extracting female lines from hybrids into a breeding routine is also associated to the number of RHA inbred lines to be altered into HA inbred lines. One way to reduce this number is to assess, before altering, the general and/or specific combining ability of the lines by using top-crosses to CMS-HA inbred lines, which are isogenic to the male line of the hybrids or to genetic male-sterile lines. Only elite lines would be bred, thus reducing the required time and labor.

Test-crossing to differentiate heterozygous from homozygous plants for the fertility restoring gene can also be facilitated, however, by the use of molecular markers. This is true for the single gene controlled CMS trait and especially helpful in those few cases reported in the literature of fertility restoration in sunflower being controlled by up to four genes (Vranceanu \& Stoenescu, 1971; Anashchenko \& Duka, 1985; Iuoras et al., 1992; Kural \& Miller, 1992). 


\section{Conclusion}

Superior female inbred lines can be extracted from sunflower hybrids by selfing a sample of individuals and by altering the obtained inbred lines carrying the fertility restorer (Rf) gene into inbred lines with normal cytoplasm without the Rf gene, followed by the introduction of the male-sterile cytoplasm.

\section{References}

ANASHCHENKO, A.V.; DUKA, M.V. Study of the genetic system of CMS-Rf in sunflower (Helianthus annuus L.) III. Restoration of male fertility in the $\mathrm{CMS}_{1}$-based hybrids. Genetika, v.21, p.2005-2010, 1985.

IUORAS, M.; VRANCEANU, A.V.; BERVILLE, A. Cytoplasm: nucleus relationships in the CMS pollen fertility restoration in Fundulea 1 (ANT-1) CMS of sunflower. In: INTERNATIONAL SUNFLOWER CONFERENCE, 13., 1992, Pisa. Proceedings. Paris: International Sunflower Association, 1992. p.1072-1077.

KURAL, A.; MILLER, J.F. The inheritance of male fertility restoration of the PET2, G1G1 e MAX1 sunflower cytoplasmic male sterility sources. In: INTERNATIONAL SUNFLOWER CONFERENCE, 13., 1992, Pisa. Proceedings. Paris: International Sunflower Association, 1992. p.1107-1112.

MILLER, J.F.; FICK, G.N. The genetics of sunflower. In: SCHNEITER, A.A. (Ed.). Sunflower technology and production. Wisconsin: ASA-CSSA-SSSA, 1997. p.441-495.
MILLER, J.F.; GREEN, C.E.; LI, Y.M.; CHANEY, R.L. Registration of three low cadmium (HA 448, HA 449, and RHA 450) confection sunflower genetic stocks. Crop Science, v.46, p.489-490, 2006 a.

MILLER, J.F.; GULYA, T.J. Registration of two restorer (RHA 439 and RHA 440) and one maintainer (HA 441) Sclerotinia-tolerant oilseed sunflower germplasms. Crop Science, v.46, p.482, 2006.

MILLER, J.F.; GULYA, T.J.; SEILER, G.J. Registration of five fertility restorer sunflower germplasms. Crop Science, v.42, p.989-991, 2002.

MILLER, J.F.; GULYA, T.J.; VICK, B.A. Registration of imidazolinone herbicide-resistant maintainer (HA 442) and fertility restorer (RHA 443) oilseed sunflower germoplasms. Crop Science, v.46, p.483-484, $2006 \mathrm{~b}$.

MILLER, J.F.; GULYA, T.J.; VICK, B.A. Registration of three maintainer (HA 444 to HA 446) and one restorer (RHA 447) high oleic oilseed sunflower germplasms. Crop Science, v.46, p.484-485, 2006c.

MILLER, J.F.; SEILER, G.J. Registrations of five oilseed maintainer (HA 429-HA 433) sunflower germplasm lines. Crop Science, v.43, p.2313-2314, 2003.

MILLER, J.F.; VICK, B.A. Registration of four high linoleic sunflower germplasms. Crop Science, v.41, p.602, 2001

MILLER, J.F.; VICK, B.A. Registration of four mid-range oleic acid sunflower genetic stocks. Crop Science, v.42, p.994, 2002.

SERIEYS, H. Identification, study and utilization in breeding programs of new CMS sources. Helia, v.19, p.144-160, 1996.

VRANCEANU, V.A.; STOENESCU, F.M. Pollen fertility restorer gene from cultivated sunflower (Helianthus annuus L.). Euphytica, v.20, p.536-541, 1971. 